\title{
DO GENERIC STRATEGY AND PRODUCTIVITY HELP DETECT CORPORATE RETAIL BANKRUPTCY RISK?
}

\author{
Steph SUBANIDJA ${ }^{*}{ }^{*}$, Sri WAHYUNI ${ }^{\circledR}$, Melda LESTARI, Wilfridus B. ELU \\ School of Postgraduate, Perbanas Institute, Jakarta, Indonesia
}

Received 24 May 2019, accepted 15 November 2019

\begin{abstract}
Recently, there have been several retail companies experiencing bankruptcy. Many studies on bankruptcy risk are more seen from the financial performance perspective. Studies on the risk of financial performance are good but it seems too late to detect the risk. So far, no research investigates some antecedents on the risk directly. It is commonly ended in financial performance. This study detects earlier the risk from antecedents of financial performance as an indicator of the risk. The study aims to investigate the effect of generic strategy, as well as productivity, on bankruptcy. The study is causality research. The population is 25 retail companies. With certain criteria, there are 17 companies as a sample. By using SEM and smart-PLS, it can be concluded that cost leadership affects both on productivity and the risk. Then, the differentiation strategy does not affect productivity, but it affects the risk. Furthermore, productivity is eligible as an intervening variable on the risk. Moreover, the strategy and productivity are good but not enough to detect the risk. Therefore, for detecting the risk possibility, it is needed a further research improvement for detecting the risk from a macro and micro perspective comprehensively.
\end{abstract}

Keywords: differentiation, cost leadership strategy, productivity, bankruptcy risk, retail companies.

JEL Classification: G33, M11, M21, M41, L81.

\section{Introduction}

Recently, a lot of news reported that some retail companies are at bankruptcy risk. Indicators of the bankruptcy risk, in general, are viewed from the financial performance perspective. Nevertheless, what caused the financial performance of several retail companies tend to decline? The decline of the performance, from time to time, indicates a risk. Moreover, the performance is commonly used as an early warning for detecting corporate bankruptcy risk.

O'Hara et al. (2000) mentioned that there is a correlation between financial performance and its stock price, whereas the stock price is influenced by macro-economy indicators (Ali et al., 2010). Meanwhile, corporate bankruptcy risk can be predicted by its financial performance (Calandro, 2007). Therefore stock price can be used as a signal of financial performance. So, there is a link between macro-economy, stock price, financial performance, and bankruptcy risk, and in general, the risk is determined by micro and macro conditions.

Over the past five years, Indonesia is facing the phenomenon that retail company stock prices have tended to decline. From 17 (seventeen) of the retail companies, it is only 6 (six) companies that have a positive trend. It means that most of the companies (64.7\%) have a decreasing trend of financial performance. Moreover, it seems that the companies are facing a bankruptcy risk.

However, the risk is most frequently seen from a micro perspective that is financial performance. The only view of studies investigates the risk from antecedents of financial performance such as generic strategic, corporate social responsibility, good corporate governance, intellectual capital, and customer satisfaction. From the macro perspective, Takahashi, Taques, and Basso (2018) mentioned that in general bankruptcies may be a consequence variable of certain economic and/or financial crises.

From the micro perspective, Bryan, Fernando, and Tripathy (2013) mentioned that pursuing a successful generic strategy has a positive effect on firm financial performance and the performance was mediated by productivity variable. Moreover, Bhattarai (2018) placed cost leadership and differentiation strategy as an independent variable on financial performance, whereas Cenciarelli et al. (2018) used intellectual capital as an antecedent of financial performance. Besides, Darrat et al. (2016) investigated good

*Corresponding author. E-mail: ssubanidja@gmail.com

This is an Open Access article distributed under the terms of the Creative Commons Attribution License (http://creativecommons.org/licenses/by/4.0/), which permits unrestricted use, distribution, and reproduction in any medium, provided the original author and source are credited. 
corporate governance as an independent variable on performance. Moreover, Hasan, Kobeissi, and Wang (2018) informed that corporate social responsibility affects financial performance with mediating by productivity.

From both macro and micro perspectives, some variables are affecting the financial performance and the performance informs a prediction of bankruptcy risk. However, the phenomena show that bankruptcy risk still happens. It seems because the previous researches, analyzed the risk partially, whether from a macro or micro perspective. From a micro perspective, so far, no research analyzed some variables that affect the bankruptcy risk directly. It is just ended at financial performance. Then the bankruptcy risk is analyzed separately by using the performance.

Referring to the phenomenon of retail bankruptcy in Indonesia, decreasing of stock price and the results of research by Bryan, Fernando, and Tripathy (2013), and Bhattrai (2018), this study investigates whether cost leadership and differentiation strategy help detect bankruptcy risk, with productivity as an intervening variable?

\section{Review of literature}

In general, risk prediction studies of corporate bankruptcy are mostly viewed from a financial performance perspective (Akbar et al., 2019; Adnan \& Dar, 2006; Altman et al., 1977; Altman, 1968; Beawer, 1968; Beaver, 1966). Meanwhile, some studies investigated corporate bankruptcy risk from perspectives of methodology (Garcia, et al., 2019; Nyitrai, 2019; Kim, Mun, \& Bae, 2018).

There are at least seven models for predicting bankruptcy risk. The models are Altman Z score (1968), Ohlson (1980), Zeta (Kasilingam \& Ramasundaram, 2012), Springate (Aghajani \& Jouzbarkand, 2012; Fulmer (Kasilingam \& Ramasundaram, 2012), indexes IN01 and IN05 (Gavurova, et al., 2017). In terms of using Altman Z-score, Sulud (2014) and Hayes, Hodge, and Hughes (2010) argued that the Altman Z-score model is the first model for predicting bankruptcy risk and better than others, although that it still cannot be generalized.

As an intervening variable, productivity can be explained as a ratio of total output and total input (Bryan, Fernando, \& Tripathy, 2013). Furthermore, it is said that higher productivity allows companies to produce output with fewer inputs so that there is a reduction in production costs. Besides, Movahed and Shamszadeh (2015) concluded that productivity has a predictive effect on financial performance. On the other hand, an increase in global competition and rapid technological development caused management has to think and be responsive to changes in resource productivity (Blocher, Stout, \& Cokins, 2010).

Furthermore, Bryan, Fernando, and Tripathy (2013) mentioned that companies can compete with their competitors through at least two elements of generic strategy. The elements are differentiation and cost leadership. Moreover, cost leadership can be achieved through cost efficiency and asset savings. With input prices lower than competitors, companies can sell goods and services at lower prices as well. If consumers choose prices as the main consideration in purchasing or using services, the company will take benefit from implementing cost leadership strategies. It was also argued that the cost leadership strategy is strongly connected with the development of productivity. This is because productivity is the ability to combine different inputs to produce certain outputs. A basic principle of the strategy is to reduce costs for all actions. Thus, a gap between prices in the market and costs will be greater, and the company will gain a competitive advantage (Kurt \& Zehir, 2016).

(Blocher, Stout, \& Cokins, 2010) stated that differentiation strategy is a competitive strategy. Furthermore, it is said that companies tend to be successful by developing and maintaining the uniqueness of a product. The uniqueness is most likely seen from the customer's perception. Companies that adopt a differentiation strategy gain a competitive advantage. Companies that take a differentiation strategy invest in developing unique products or services. So that companies can become price leaders in their market (Banker, Mashruwala, \& Tripathy, 2014). Furthermore, Orcullo (2007) mentioned that the best way to get a sustainable competitive advantage in the area of a differentiation strategy is: a. new product innovation, b. technical excellence, c. product quality and reliability, d. comprehensive customer service, and e. unique competitive capability. Moreover, Barney and Hesterly (2019) mentioned that product differentiation can create customer preferences and it allows the company to make an above-normal profit. It is also that almost anything can be a base of differentiation. Moreover, the preferences are evidence of a product differentiation that increases the volume of purchase and or a premium price of the product.

Researches on the influence of corporate strategy on bankruptcy risk were previously carried out by Bryan, Fernando, and Tripathy (2013), Movahed and Shamszadeh (2015) and Bhattarai (2018). Places of research are conducted in different companies and countries, but there are similarities in research results, namely, cost leadership and differentiation strategy affect company performance. The further result said that productivity, as an intervening variable, has a significant effect on the risk of company performance. Moreover, productive companies will be able to generate a greater income than their expenses. With stable financial conditions, bankruptcy risk will be lower.

Besides, Bhattarai (2018) stated that cost leadership and differentiation strategy have a positive impact on the sustainability of financial performance, but there is no more information about its impact on the risk of bankruptcy. Another research found that intellectual capital is negatively associated with the probability of company defaults (Cenciarelli, Greco, \& Allegrini, 2018). Another variable that effects on bankruptcy risk are good corporate governance variable. Darrat et al. (2016) mentioned that corporate governance for complex firms with larger boards of directors reduces bankruptcy risk. So that to 


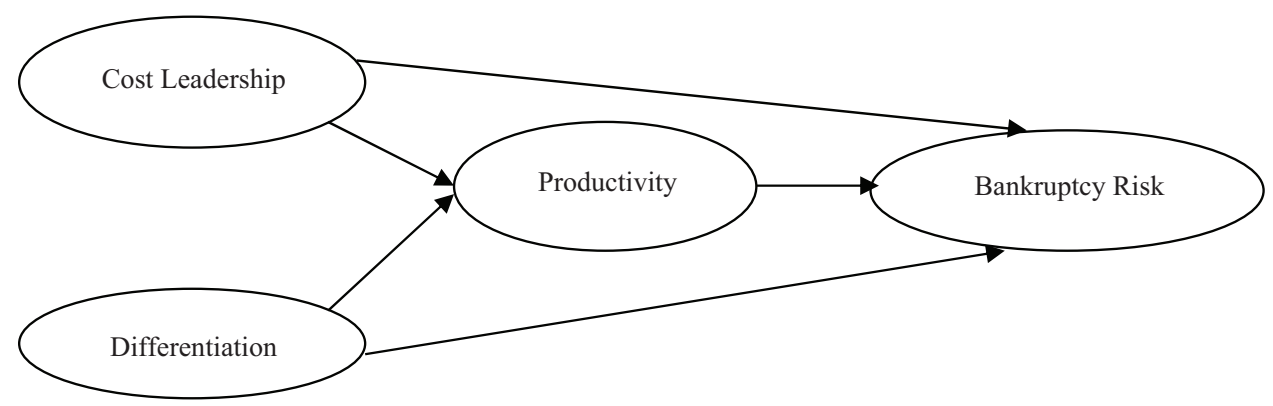

Figure 1. Research model (adapted from Bryan, Fernando, and Tripathy (2013), Movahed and Shamszadeh (2015) and Bhattarai (2018))

predict a company bankruptcy risk, the risk can be predicted through financial risk, cost leadership strategy, differentiation strategy, intellectual capital, and good corporate governance. Due to there is not enough information on company retail financial statements, this study analyzes 4 (four) variables, namely cost leadership strategy, differentiation strategy, productivity, and bankruptcy risk.

The kinds of literature review investigated the effect of cost leadership strategy, differentiation strategy, and productivity on financial performance, whereas the financial performance is an instrument to predict a bankruptcy risk. This research investigates the effect of the three variables on the bankruptcy risk directly. So, based on the review and the novelty of this research, the research model can be seen in Figure 1.

\section{Methodology}

This study is quantitative causality research. There are two independent variables, namely cost leadership and differentiation strategy, one intervening variable, namely productivity, and one dependent variable, namely bankruptcy risk. The object of the study is Indonesian retail companies listed on the IDX for financial statements data from January 2014 to December 2018. It means that the analyzed data is panel data.

Cost leadership strategy is measured by using three proxies. The proxy measurement refers to the concept of Balsam, Fernando, and Tripathy (2011) and Asdemir, Fernando and Tripathy (2013). First, the proxy of the cost leadership strategy are 1) ratio of net sales to capital expenditures, 2) ratio of net sales to net book value of land and equipment, and 3) ratio of the number of employees to total assets used to measure labor efficiency. However, in this study, a cost leadership strategy is only measured by using the first and second proxy. The third proxy is not utilized considering that the number of employees in retail companies is not feasible to be juxtaposed with the company's total assets. Moreover, proxies of a differentiation strategy are 1) ratio of sales, general and administrative expenses to net sales, 2) ratio of research and development to net sales and 3) ratio of net sales to cost of goods sold. These proxies of the differentiation strategy are also supported by Barney and Hesterly (2019) that customer preferences are product differentiation which can increase the volume of sales.

The proxy of bankruptcy risk is measured by using Altman Z-Score (Calandro, 2007), with five variables. These variables are working capital/total assets, retained earnings/total assets, EBIT/total assets, the market value of equity/book value of total liabilities and sales / total assets. Criteria that are used to interpret the Z-Score are a safe zone for Z-score is greater than 2.99, distress zone for $\mathrm{Z}$ score is lower than 1.81 and the gray zone is between 1.81 and 2.99 (Calandro, 2007).

Variable of productivity is considered to be able to mediate between cost leadership strategy and differentiation, and bankruptcy risk. The productivity value is obtained by dividing the total output by the total input. The population of this study is all 25 companies listed on the IDX. With certain considerations, it is not all members of the population are examined. Criteria for choosing a sample are 1) companies are listed in the IDX until 2018,2) companies are engaged in the retail subsector, and 3) companies have complete data to analyze. With these criteria, 17 companies are eligible to analyze.

Data analysis used SEM (Structural Equation Model) approach with smart-PLS (Partial Least Square) software. Götz, Liehr-Gobbers, and Krafft (2010) stated the PLS approach is appropriate for explorative analysis of structural equation models. The stages of data analyzed are as follows. First, it is the test of the outer model. The outer model testing is applied to see a correlation between indicator and score of the construct. The indicator is considered reliable if the correlation value is above 0.60 . Second, it is the inner model test. The inner model test is commonly known as a structural model test. This test is conducted to see the relationship between variables, namely significance values and R-square from a research model. Third, it is hypothesis testing. The hypothesis is applied to find out whether temporary allegations made by the researcher are accepted or rejected. Criteria for accepting or rejecting the hypothesis are based on the p-value.

\section{Results}

The research results can be grouped into variables description, testing of the outer and inner model, hypotheses testing and discussion as follows. 


\subsection{Variables description}

The first proxy of cost leadership strategy is the ratio of sales to capital expenditure which illustrates a level of efficiency of the company is using assets. The greater value of the ratio means the company is considered more efficient. Capital expenditures made by the company make a positive contribution to sales. The increase in capital expenditure should be directly proportional to the increase in sales. From 17 retail companies studied, there are 4 companies whose sales ratio to capital expenditure decreased from 2014 to 2018. This indicates that an increase in capital expenditure does not contribute positively to sales. Companies that have increased efficiency are 7 companies. This shows that capital expenditure can increase sales. The rest experienced fluctuations. Companies with fluctuating ratios illustrate that an increase in capital expenditure does not always make sales higher (see Appendix 1).

The second proxy of cost leadership is the ratio of sales to book value of assets. The higher sales ratio of the book value of fixed assets indicates higher efficiency in the use of assets. High ratio figures reflect that fixed assets owned by the company are used optimally and may contribute to increased sales. Results indicate that six companies have a trend that tends to increase from year to year. It can be said that the company can use existing fixed assets to increase sales. Six other companies have a trend that tends to fall. This indicates that the company is unable to use fixed assets to increase sales. This decrease can be caused by two things. First, it is the increase in fixed assets without increasing sales. Second, it is the number of fixed assets of the company that has not changed, but sales that have decreased. Other companies that are not mentioned have a volatile trend (see Appendix 2).

The first proxy of a differentiation strategy is sales and operating costs. A retail company operating costs are generally divided into two components. First, there is the cost of sales. Second, there are general and administrative costs. Companies that carry out the differentiation strategy will invest in various marketing activities to differentiate themselves from competitors. Marketing costs themselves are sub-sections in sales costs that are variable. More companies want to differentiate themselves from competitors, the greater the costs incurred. Cost is expected to be directly proportional to sales. A smaller ratio number, the better the company manages operating costs to increase sales. From 17 companies analyzed, the majority have to fluctuate of SG \& A/Sales ratios. Only one company tends to decrease from year to year. This decline indicates that the company can manage the increase in sales higher than the increase in operating costs. On the other hand, seven companies have a ratio with an upward trend. This means that sales growth is no greater than the growth in company operating costs (see Appendix 3).

The second proxy used in calculating differentiation strategy is the ratio of research and development costs to sales. The key to success for companies to be different from competitors is to provide high-quality and innovative goods and services. Thus, consumers will provide more value and tend to remember the goods and services owned by the company than those of competitors. To be different and win the market, the costs of research and development will be higher. The smaller the ratio shows better conditions. Results show that five companies have an uptrend. This means that sales growth is greater than growth in research and development costs. On the other hand, three companies have a different trend. Other companies that are not mentioned have a fluctuating trend (see Appendix 4).

The third proxy of a differentiation strategy is the sales ratio to the cost of goods sold. The success of a company adopting a differentiation strategy is measured by its ability to determine a higher price. The prices will not be a problem for consumers because the company is unique in terms of goods and services produced. Results show that only four companies have performed. This indicates that the company can control the increase in sales above the increase in the cost of goods. On the other hand, five companies experience the opposite. The ratio of sales to the cost of goods has decreased. Growth in basic prices is greater than sales growth (see Appendix 5).

In terms of productivity, it can be summarized that there is no company in which productivity has a rising trend. Four companies have decreased their productivity. This indicates that an increase in sales is not greater than an increase in costs. While 13 other companies have a fluctuating trend (see Appendix 6)

In terms of bankruptcy risk, there are various approaches to calculate the bankruptcy risk. In this study, bankruptcy risk is calculated using the Altman Z-Score approach. The Score formula consists of several ratios, namely working capital to total assets, retained earnings to total assets, operating income to total assets, equity market value to total debt and sales to total assets. Each ratio is then multiplied by a predetermined constant. It can be seen that not all companies are in a safe position in 2018. Three companies have value $Z<1.81$. Besides, three companies are in a vulnerable or gray area position. The Z-score of the three companies is between 1.81 and 2.99. It means that there are six of seventeen retail companies are not in save performance (see Appendix 7).

\subsection{Testing of outer and inner model}

The data analysis method in this study is SEM, with the software used is smart-PLS. The result of the full model can be seen in Figure 2 .

The result of the model in Figure 2 can be used as outer and inner model tests as follows. There are three criteria used to test the outer of a model. The criteria are convergent validity, discriminant validity, and composite reliability. The limit of the correlation value used is equal to or greater than 0.6. First, the outer test of the cost leadership strategy model is used by two proxies. The correlation value for the first proxy is 0.886 and the second 


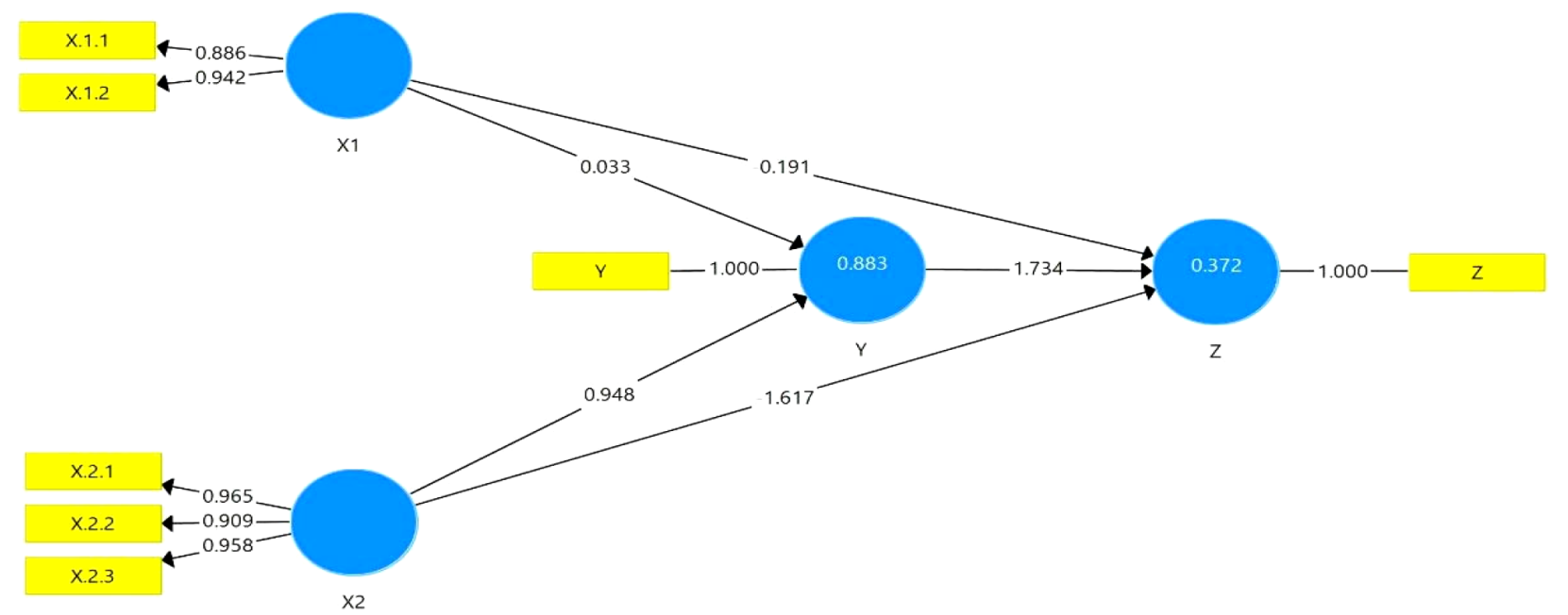

Figure 2. A full model of research result

one is 0.942 . Both values are above the value of 0.6 . It can be concluded that the proxies meet the requirements for model adequacy. Second, the test of the differentiation strategy outer model, resulting in that all proxies used have fulfilled the correlation value above the value of 0.60 . Thus, the differentiation strategy variable has met the convergent validity of a model and can proceed to the next data processing. Third, the test of the outer model productivity variable informs a correlation value above the value of 0.60 . Thus the productivity variable calculated by dividing the number of inputs per output is feasible and can proceed to the next data processing. Finally, the test of bankruptcy risk outer model results that the Z-score value meets the adequacy of the model with a correlation value of more than 0.60 .

The second test is the inner model test. The test is also known as a structural model test. This test is conducted to see the relationship between variables, significance values, and R-square research models. Model assessment begins by looking at the R-square of the dependent variable. Changes in the value of R-square can be used to see how the independent variables influence the dependent variable. The R-square value of productivity is 0.883 and the bankruptcy risk is 0.372 . The higher the $\mathrm{R}$-square value means the greater the ability of an independent variable to explain the dependent variable. This makes structural equations better.

The company productivity variable has a value of Rsquare that is 0.883 . This means that the cost leadership strategy and differentiation strategy can explain $88.3 \%$ of the productivity variable. The R-square value indicates that the model is in a strong category. This finding means that better cost leadership and differentiation strategy, the company has a higher level of productivity. Furthermore, the bankruptcy risk variable has an R-square value of 0.372 . The meaning of this value is that cost leadership, differentiation strategy and productivity can explain a $37.2 \%$ changing in bankruptcy risk variable. The remaining of $62.8 \%$ of bankruptcy risk is explained by other factors outside the research model. Other factors in question can be in the form of company value, company liquidity, company image to the economic condition of a country where the company conducts its business activities. Based on the R-square value, this model is a moderate level. This finding explains that if the generic porter strategy and company productivity gets better, the Altman Z-score will be higher. The higher of Altman Z-score indicates that the company avoids bankruptcy risk.

\subsection{Hypotheses testing}

Based on Figure 1, there are seven hypothesis testing. The hypothesis is based on p-value and the limit for accepting or rejecting a hypothesis is $5 \%$. The result summary of hypotheses testing is shown in Table 1.

Table 1. Result summary of hypotheses testing

\begin{tabular}{|c|c|c|c|}
\hline Variable & $\begin{array}{c}\text { Original Sample } \\
\text { Estimate }\end{array}$ & $\mathrm{t}$ - Statistics & $\mathrm{p}$-Values \\
\hline $\mathrm{X}_{1}-\mathrm{Y}$ & 0.033 & 0.282 & 0.778 \\
\hline $\mathrm{X}_{2}-\mathrm{Y}$ & 0.948 & 7.867 & 0.000 \\
\hline $\mathrm{X}_{1}-\mathrm{Z}$ & -0.191 & 0.607 & 0.544 \\
\hline $\mathrm{X}_{2}-\mathrm{Z}$ & -1.617 & 1.288 & 0.199 \\
\hline $\mathrm{Y}-\mathrm{Z}$ & 1.734 & 1.683 & 0.093 \\
\hline
\end{tabular}

Based on Table 1, it can be summarized the results of the hypothesis as follows. Hypothesis 1 states that a cost leadership strategy $\left(\mathrm{X}_{1}\right)$ does not influence bankruptcy risk $(\mathrm{Z})$. It is known that the p-value between cost leadership strategy and bankruptcy risk is 0.544 . This value is greater than the required value, namely 0.05 . Thus the first hypothesis is rejected. Then, it is concluded that the cost leadership strategy affects bankruptcy risk in retail companies in Indonesia.

Hypothesis 2 states that a differentiation strategy $\left(\mathrm{X}_{2}\right)$ does not influence bankruptcy risk $(\mathrm{Z})$. The result shows that the p-value between cost differentiation strategy and bankruptcy risk is 0.199 . This value is greater than the required value. It means that the second hypothesis 
is rejected. So, it is said that the differentiation strategy affects bankruptcy risk in retail companies in Indonesia.

Hypothesis 3 states that a cost leadership strategy (X1) does not influence company productivity $(\mathrm{Y})$. The calculation result shows that the $\mathrm{p}$-value between cost leadership strategy and productivity is 0.778 . This value is greater than the required value. Thus the third hypothesis is rejected. It is concluded that cost leadership strategy affects the productivity of retail companies in Indonesia.

Hypothesis 4 states that a differentiation strategy (X2) does not influence productivity $(\mathrm{Y})$. It is known that the $\mathrm{p}$ value between differentiation strategy and productivity is 0,000 . This value is smaller than the required value. Thus the fourth hypothesis is accepted. It can be said that the differentiation strategy does not affect the productivity of retail companies in Indonesia.

Hypothesis 5 states that productivity $(\mathrm{Y})$ does not influence bankruptcy risk (Z). It is known that the p-value between productivity and bankruptcy risk is 0.093 . This value is greater than the required value. Thus the fifth hypothesis is rejected. It is concluded that productivity affects bankruptcy risk in retail companies in Indonesia.

Table 2. Result summary of direct and indirect effect

\begin{tabular}{|l|c|c|c|}
\hline \multicolumn{1}{|c|}{ Effect } & Direct Effect & Indirect Effect & $\mathrm{p}$-Values \\
\hline $\mathrm{X}_{1}$ on $\mathrm{Z}$ & 0.191 & & \\
\hline $\mathrm{X}_{1}$ on $\mathrm{Y}$ & 0.033 & & \\
\hline $\mathrm{Y}$ on $\mathrm{Z}$ & 1.734 & & \\
\hline $\mathrm{X}_{1}$ on $\mathrm{Y}$ on $\mathrm{Z}$ & & 0.057 & 0.738 \\
\hline $\mathrm{X}_{2}$ on $\mathrm{Z}$ & 1.617 & & \\
\hline $\mathrm{X}_{2}$ on $\mathrm{Y}$ & 0.948 & & \\
\hline $\mathrm{Y}$ on $\mathrm{Z}$ & 1.734 & & \\
\hline $\mathrm{X}_{2}$ on $\mathrm{Y}$ on $\mathrm{Z}$ & & 1.644 & 0.114 \\
\hline
\end{tabular}

In order to explain a direct and indirect effect (Table 2) of the independent variables on the bankruptcy risk, through a variable of productivity, it can be summarized further hypothesis. Hypothesis 6 informs the direct and indirect effect of cost leadership strategy on bankruptcy risk through productivity, whereas hypothesis 7 describes both direct and indirect effect of differentiation strategy on the risk through a variable of productivity as an intervening variable

Hypothesis 6 states productivity $(\mathrm{Y})$ mediates a relationship between cost leadership strategy (X1) and bankruptcy risk ( $\mathrm{Z})$. It is known that the $\mathrm{p}$-value between cost leadership strategy and bankruptcy risk mediated by productivity is 0.738 . This value is greater than the required value. Thus the sixth hypothesis is rejected. It is concluded that productivity mediates the causal relationship between cost leadership strategy and the bankruptcy risk of retail companies in Indonesia.

Hypothesis 7 states productivity $(\mathrm{Y})$ mediates the relationship between differentiation strategy (X2) and bankruptcy risk (Z). It is known that the p-value between differentiation strategy and bankruptcy risk with productivity as the intervening variable is 0.114 . This value is greater than the required value. Thus the seventh hypothesis is rejected. It is concluded that productivity mediates the relationship between differentiation strategy and bankruptcy risk of retail companies in Indonesia.

\subsection{Discussion}

The first hypothesis result indicates that the bankruptcy risk experienced by companies is affected by the cost leadership strategy. Cost leadership strategy helps companies to be able to manage costs used during production to be lower. With low production costs, the selling price of goods or services will be cheaper. The cheaper selling prices are expected to attract more consumers and retain existing consumers. If the target market is consumers with price-oriented, then the cost leadership strategy will be very suitable.

In this study, retail companies, there is no production process from raw materials to finished goods. All items sold at outlets or stores are goods from suppliers or distributors. This causes retail companies can set prices according to what they want. Many factors need to be considered when setting a selling price. The factors in question include the perception of the price of an item or service, the price offered by a competitor, the current economic condition of the community and other factors. The results of this study in line with the research of Movahed and Shamszadeh (2015), and Bryan, Fernando, and Tripathy (2013), which stated that cost leadership strategy influences decreasing the risk of corporate bankruptcy.

The second hypothesis result states that the differentiation strategy affects bankruptcy risk. If traced, there are three elements in calculating differentiation strategies. They are ratios of operating costs to sales, ratio of research and development costs to sales and ratio of sales to the cost of goods sold. From the three ratios, only sales are used in the Altman Z-Score formula. So, it is natural that the high and low risk of a company's bankruptcy is influenced by the differentiation strategy. Then, the differentiation strategy is used by companies to create a uniqueness that can attract consumers. Besides, for attracting consumers, the uniqueness is also expected to increase brand awareness. These two things are something that seems to appear in both a short and long term period. Because of this, the differentiation strategy does necessarily affect on bankruptcy risk of retail companies in Indonesia.

The third hypothesis result states that a cost leadership strategy affects productivity. Retail company productivity in this study is measured by calculating total input to total output. The input in question is sales, while the output is costs to generate a sale. The company's strategy based on the period is divided into three, namely long-term, medium-term and short-term strategies. The generic strategy is included in the long-term strategy. Increasing sales and lowering costs are something that can be done naturally and strategically by a company. Retail companies depend 
on suppliers in determining the selling price and cost of goods sold. This makes a cost leadership strategy does affect productivity.

The fourth hypothesis result informs that the differentiation strategy does not influence productivity. The result contradicts with the research of Movahed and Shamszadeh (2015) and Bryan, Fernando, and Tripathy (2013). The better the company makes a differentiation strategy, the uniqueness of the goods or services offered will be increasingly embedded in the minds of consumers. That way, consumers will make a company main reference when making a purchase. This will increase sales volume and customer loyalty. Increasing sales will make productivity better. However, from a customer point of view, product differentiation cannot happen instantly. It is needed some effort and takes time to make the product becoming "top of mind" that the products seem different from others.

The fifth hypothesis result shows that bankruptcy risk is affected by company productivity. The result is in line with the research of Movahed and Shamszadeh (2015) and Bryan, Fernando, and Tripathy (2013) which stated that productivity influences reducing the risk of corporate bankruptcy. Companies that experience an increase in productivity do not always experience a bankruptcy risk. However, from 17 companies studied, there are 9 companies in which productivity changes are in line with bankruptcy risk. This study shows that productivity is dominant as the cause of bankruptcy risk.

The sixth and seventh hypothesis results which state that productivity mediates the relationship between Porter's generic strategy and bankruptcy risk are proven in this study. This is in line with Movahed and Shamszadeh (2015) and Bryan, Fernando, and Tripathy (2013) research. In the previous discussion, it is mentioned that cost leadership and differentiation strategy, affect bankruptcy risk. After adding other variables, namely, productivity which is considered to be able to mediate the relationship between the strategy and risk variables, the bankruptcy risk can be detected by the generic strategy which mediated by productivity.

Based on the results of the study, it is argued that proxy used to calculate company productivity is sufficient enough to represent the independent and dependent variables. Productivity as an intervening variable is expected to mediate the relationship between the porter's generic strategy and the bankruptcy risk. Furthermore, after testing, changes are happening with the use of productivity as an intervening variable. According to Baron and Kenny (1986), the role of a variable as a mediator will occur if: 1) independent variables have a significant effect on the dependent variable in the first equation, 2) independent variables have a significant effect on the intervening variable in the second equation, 3 ) intervening variables must have an effect significant to the dependent variable in the third equation. From the statement above, almost all of the conditions are fulfilled in the study. The test results show that only the differentiation strategy does not influence productivity. Meanwhile, other variables have an influence. For this reason, productivity can be placed as an intervening variable between cost leadership strategy and differentiation strategy on bankruptcy risk of retail companies in Indonesia. Furthermore, productivity is a strong signal to explain bankruptcy risk.

\section{Conclusions and managerial implication}

The study concluded that firstly, cost leadership and differentiation strategy affect bankruptcy risk in retail companies listed on the Indonesia Stock Exchange. Secondly, cost leadership strategy affects productivity in retail companies, but a differentiation strategy does not affect productivity. Thirdly, productivity affects bankruptcy risk. Fourthly, the indirect effect of the generic strategy is greater than the direct effect on the bankruptcy risk, so productivity can mediate the cause-effect relationship between cost leadership strategy and bankruptcy risk in retail companies. Finally, differentiation and cost leadership strategy, with productivity as an intervening variable, able to detect the bankruptcy risk of the retail companies through productivity. Although the cost leadership and differentiation strategy are just natural things and generally well implemented by companies, these strategies are still good but not enough to predict a reluctance of retail companies in Indonesia especially through a signal of productivity. Finally, the study found that to predict the bankruptcy risk through financial performance is good. To detect earlier the risk from productivity and generic strategy are also good, but it is still not enough due to that mostly the bankruptcy risk, is influenced by outside of the independent variables.

Based on conclusions, it seems that probably, the best way to detect the bankruptcy risk, first it is from external conditions then second it is from internal conditions. It is recommended that although bankruptcy risk can be detected and commonly predicted by company micro perspectives, such as financial performance, generic strategy, productivity, good corporate governance, corporate social responsibility, customer satisfaction, and intellectual capital, the company should also implement managerial practical analysis starting the risk first, it is from macro perspectives such as financial crisis, global competitiveness and especially rapid technological development, then second, it is from micro perspectives such as financial performance, strategies which are used and implemented and other related matters. It means that it is needed compressive research from macro and micro perspectives simultaneously.

\section{Acknowledgements}

The article is fully and financially supported by Perbanas Institute Jakarta, Indonesia. 


\section{References}

Adnan Aziz, M., \& Dar, H. A. (2006). Predicting corporate bankruptcy: where we stand? Corporate Governance: The International Journal of Business in Society, 6(1), 18-33. https://doi.org/10.1108/14720700610649436

Aghajani, V., \& Jouzbarkand, M. (2012). The creation of bankruptcy prediction model using Springate and SAF Models. World Applied Sciences Journal, 17, 1-5.

Akbar, A., Akbar, M., Tang, W., \& Qureshi, M. A. (2019). Is bankruptcy risk tied to corporate life-cycle? Evidence from Pakistan. Sustainability, 11(3), 678. https://doi.org/10.3390/su11030678

Ali, I., Rehman, K. U., Yilmaz, A. K., Khan, M. A., \& Afzal, H. (2010). The causal relationship between macro-economic indicators and stock exchange prices in Pakistan. African Journal of Business Management, 4(3), 312-319.

Altman, E. I. (1968). Financial ratios, discriminant analysis and the prediction of corporate bankruptcy. The Journal of Finance, 23(4), 589-609. https://doi.org/10.1111/j.1540-6261.1968.tb00843.x

Altman, E. I., Haldeman, R. G., \& Narayanan, P. (1977). ZETATM analysis A new model to identify bankruptcy risk of corporations. Journal of Banking \& Finance, 1(1), 29-54. https://doi.org/10.1016/0378-4266(77)90017-6

Asdemir, O., Fernando, G. D., \& Tripathy, A. (2013). Market perception of firm strategy. Managerial Finance, 39(2), 90-115. https://doi.org/10.1108/03074351311293972

Balsam, S., Fernando, G. D., \& Tripathy, A. (2011). The impact of firm strategy on performance measures used in executive compensation. Journal of Business Research, 64(2), 187-193. https://doi.org/10.1016/j.jbusres.2010.01.006

Barney, J. B., \& Hesterly, W. S. (2019). Strategic management and competitive advantage: Concepts and cases. Pearson.

Banker, D. R., Mashruwala, R., \& Tripathy, A. (2014). Does a differentiation strategy lead to more sustainable financial performance than a cost leadership strategy? Management Decision, 52(5), 872-896. https://doi.org/10.1108/MD-05-2013-0282

Baron, R. M., \& Kenny, D. A. (1986). The moderator-mediator variable distinction in social psychological research: Conceptual, strategic, and statistical considerations. Journal of Personality and Social Psychology, 51(6), 1173. https://doi.org/10.1037/0022-3514.51.6.1173

Beaver, W. H. (1966). Financial ratios as predictors of failure. Journal of Accounting Research, 71-111. https://doi.org/10.2307/2490171

Beaver, W. H. (1968). Market prices, financial ratios, and the prediction of failure. Journal of Accounting Research, 179-192. https://doi.org/10.2307/2490233

Bhattarai, D. (2018). Generic strategies and sustainability of financial performance of Nepalese Enterprises. Pravaha, 24(1), 39-49. https://doi.org/10.3126/pravaha.v24i1.20224

Blocher, E. J., Stout, D. E., \& Cokins, G. (2010). Cost management: A strategic emphasis. Includes index.

Bryan, D., Dinesh Fernando, G., \& Tripathy, A. (2013). Bankruptcy risk, productivity, and firm strategy. Review of Accounting and Finance, 12(4), 309-326.

https://doi.org/10.1108/RAF-06-2012-0052

Cenciarelli, V. G., Greco, G., \& Allegrini, M. (2018). Does intellectual capital help predict bankruptcy? Journal of Intellectual Capital, 19(2), 321-337.

https://doi.org/10.1108/JIC-03-2017-0047

Calandro Jr, J. (2007). Considering the utility of Altman-s Zscore as a strategic assessment and performance management tool. Strategy \& Leadership, 35(5), 37-43.

https://doi.org/10.1108/10878570710819206
Darrat, A. F., Gray, S., Park, J. C., \& Wu, Y. (2016). Corporate governance and bankruptcy risk. Journal of Accounting, Auditing \& Finance, 31(2), 163-202.

https://doi.org/10.1177/0148558X14560898

García, V., Marqués, A. I., \& Sánchez, J. S. (2019). Exploring the synergetic effects of sample types on the performance of ensembles for credit risk and corporate bankruptcy prediction. Information Fusion, 47, 88-101. https://doi.org/10.1016/j.inffus.2018.07.004

Gavurova, B., Packova, M., Misankova, M., \& Smrcka, L. (2017). Predictive potential and risks of selected bankruptcy prediction models in the Slovak business environment. Journal of Business Economics and Management, 18(6), 1156-1173. https://doi.org/10.3846/16111699.2017.1400461

Götz, O., Liehr-Gobbers, K., \& Krafft, M. (2010). Evaluation of structural equation models using the partial least squares (PLS) approach. In Handbook of partial least squares (pp. 691-711). Springer, Berlin, Heidelberg. https://doi.org/10.1007/978-3-540-32827-8_30

Hasan, I., Kobeissi, N. L., \& Wang, H. (2018). Corporate social responsibility and firm financial performance: The mediating role of productivity. Journal of Business Ethics, 149(3), 671-688. https://doi.org/10.1007/s10551-016-3066-1

Hayes, S. K., Hodge, K. A., \& Hughes, L. W. (2010). A study of the efficacy of Altman's Z to predict bankruptcy of specialty retail firms doing business in contemporary times. Economics \& Business Journal: Inquiries \& Perspectives, 3(1), 130-134.

Kaliappen, N., \& Hilman, H. (2013). Enhancing organizational performance through strategic alignment of cost leadership strategy and competitor orientation. Middle-East Journal of Scientific Research, 18(10), 1411-1416.

Kasilingam, R., \& Ramasundaram, G. (2012). Predicting the solvent of non-banking financial institutions in India using Fulmer and Springate. Journal of Services Research, 12(1).

Kim, S., Mun, B. M., \& Bae, S. J. (2018). Data depth based support vector machines for predicting corporate bankruptcy. Applied Intelligence, 48(3), 791-804. https://doi.org/10.1007/s10489-017-1011-3

Kurt, A., \& Zehir, C. (2016). The relationship between cost leadership strategy, total quality management applications and financial performance. Doğuş Üniversitesi Dergisi, 17(1), 97-110. https://doi.org/10.31671/dogus.2018.45

Movahed, L. R., \& Shamszadeh, B. (2015). Studying bankruptcy risk, productivity and firm strategy in companies listed in Tehran stock exchange. International Research Journal of Applied and Basic Sciences, 9(5), 680-685.

Nyitrai, T. (2019). Dynamization of bankruptcy models via indicator variables. Benchmarking: An International Journal. https://doi.org/10.1108/BIJ-03-2017-0052

Ohlson, J. A. (1980). Financial ratios and the probabilistic prediction of bankruptcy. Journal of Accounting Research, 109131. https://doi.org/10.2307/2490395

O’Hara, H. T., Lazdowski, C., Moldovean, C., \& Samuelson, S. T. (2000). Financial indicators of stock price performance. American Business Review, 18(1), 90.

Orcullo, N. (2007). Fundamentals of strategic management (2007 Ed.). Rex Bookstore, Inc.

Sulub, S. A. (2014). Testing the predictive power of Altman's revised Z' model: the case of 10 multinational companies. Research Journal of Finance and Accounting, 5(21), 174-184.

Takahashi, M., Taques, F. H., \& Basso, L. (2018). Altman's bankruptcy prediction model: test on a wide out of business private companies sample. iBusiness, 10(01), 21.

https://doi.org/10.4236/ib.2018.101002 


\section{APPENDIXES}

\section{Appendix 1}

Summary of proxy 1: cost leadership strategy

\begin{tabular}{|l|l|c|c|c|c|c|}
\hline \multirow{2}{*}{ Names of Company } & \multirow{2}{*}{ Stock Code } & \multicolumn{4}{c|}{ SALES/CAPEX } \\
\cline { 3 - 7 } & & 2014 & 2015 & 2016 & 2017 & 2018 \\
\hline Ace Hardware Indonesia Tbk & ACES & 46,487 & 46,856 & 36,399 & 33,939 & 38,911 \\
\hline Sumber Alfaria Trijaya Tbk & AMRT & 15,398 & 17,225 & 15,331 & 13,774 & 17,139 \\
\hline $\begin{array}{l}\text { Centratama Telekomunikasi } \\
\text { Indonesia Tbk }\end{array}$ & CENT & 0,549 & 0,429 & 1,306 & 0,589 \\
\hline Catur Sentosa Adiprana Tbk & CSAP & 52,887 & 55,659 & 36,578 & 50,587 & 23,377 \\
\hline Electronic City Indonesia Tbk & ECII & 5,116 & 10,642 & 15,974 & 15,420 & 75,951 \\
\hline Erajaya Swasembada Tbk & ERAA & 72,560 & 48,687 & 93,708 & 90,387 & 90,195 \\
\hline Golden Retailindo Tbk & GOLD & 139,180 & 295,796 & 201,260 & 1,243 & 951,066 \\
\hline Hero Supermarket Tbk & HERO & 9,005 & 9,212 & 30,127 & 33,468 & 25,960 \\
\hline Kokoh Inti Arebama Tbk & KOIN & 494,659 & 79,632 & 254,111 & $5.624,844$ & $18.390,565$ \\
\hline Matahari Department Store Tbk & LPPF & 41,615 & 46,295 & 26,944 & 29,797 & 33,980 \\
\hline MitraAdiperkasaTbk & MAPI & 10,163 & 16,645 & 16,640 & 15,753 & 11,903 \\
\hline Midi Utama Indonesia Tbk & MIDI & 31,907 & 19,526 & 15,987 & 14,293 & 21,589 \\
\hline Matahari Putra Prima Tbk & MPPA & 39,836 & 122,560 & 105,935 & 144,758 & 218,971 \\
\hline Ramayana Lestari Sentosa Tbk & RALS & 20,619 & 46,222 & 38,043 & 43,275 & 40,121 \\
\hline Supra Boga Lestari Tbk & RANC & 17,866 & 11,725 & 37,327 & 65,487 & 43,651 \\
\hline Sona Topas Tourism Tbk & SONA & 85,070 & 9,729 & 26,154 & 91,927 & 28,005 \\
\hline Tiphone Mobile Indonesia Tbk & TELE & 164,689 & $1.019,973$ & $1.255,178$ & $1.233,907$ & $2.746,392$ \\
\hline
\end{tabular}

\section{Appendix 2}

Summary of Proxy 2: cost leadership strategy

\begin{tabular}{|l|l|c|c|c|c|c|}
\hline \multirow{2}{*}{ Names of Company } & \multirow{2}{*}{ Stock Code } & \multicolumn{4}{c|}{ SALES/P\&E } \\
\cline { 3 - 7 } & & 2014 & 2015 & 2016 & 2017 & 2018 \\
\hline Ace Hardware Indonesia Tbk & ACES & 8,742 & 9,808 & 10,375 & 8,383 & 16,531 \\
\hline Sumber Alfaria Trijaya Tbk & AMRT & 10,301 & 10,297 & 10,317 & 9,768 & 10,171 \\
\hline $\begin{array}{l}\text { Centratama Telekomunikasi } \\
\text { Indonesia Tbk }\end{array}$ & CENT & 0,192 & 10,534 & 11,664 & 0,186 \\
\hline Catur Sentosa Adiprana Tbk & CSAP & 8,611 & 10,904 & 9,139 & 8,911 & 7,377 \\
\hline Electronic City Indonesia Tbk & ECII & 4,494 & 4,045 & 3,183 & 2,745 & 3,213 \\
\hline Erajaya Swasembada Tbk & ERAA & 58,849 & 35,908 & 45,821 & 44,937 & 49,876 \\
\hline Golden Retailindo Tbk & GOLD & 3,095 & 3,290 & 4,389 & 1,267 & 4,054 \\
\hline Hero Supermarket Tbk & HERO & 3,194 & 2,770 & 3,188 & 3,154 & 3,025 \\
\hline Kokoh Inti Arebama Tbk & KOIN & 193,561 & 62,629 & 63,338 & 67,614 & 81,404 \\
\hline Matahari Department Store Tbk & LPPF & 9,288 & 10,917 & 10,275 & 10,100 & 10,295 \\
\hline MitraAdiperkasaTbk & MAPI & 3,879 & 4,639 & 5,264 & 5,366 & 5,254 \\
\hline Midi Utama Indonesia Tbk & MIDI & 7,961 & 7,625 & 6,804 & 5,946 & 6,010 \\
\hline Matahari Putra Prima Tbk & MPPA & 10,962 & 10,679 & 9,442 & 8,586 & 8,453 \\
\hline Ramayana Lestari Sentosa Tbk & RALS & 4,151 & 4,262 & 4,150 & 4,578 & 4,552 \\
\hline Supra Boga Lestari Tbk & RANC & 7,484 & 6,079 & 7,953 & 9,051 & 9,398 \\
\hline Sona Topas Tourism Tbk & SONA & 4,622 & 4,028 & 5,001 & 6,319 & 7,689 \\
\hline Tiphone Mobile Indonesia Tbk & TELE & 67,129 & 100,864 & 134,693 & 178,871 & 205,828 \\
\hline
\end{tabular}




\section{Appendix 3}

Summary of Proxy 1: differentiation strategy

\begin{tabular}{|l|l|l|l|l|c|c|}
\hline \multirow{2}{*}{ Names of Company } & \multirow{2}{*}{ Stock Code } & \multicolumn{4}{c|}{ SG\&A/SALES } \\
\cline { 4 - 7 } & & 2014 & 2015 & 2016 & 2017 & 2018 \\
\hline Ace Hardware Indonesia Tbk & ACES & 0,020 & 0,337 & 0,332 & 0,329 & 0,331 \\
\hline Sumber Alfaria Trijaya Tbk & AMRT & 0,159 & 0,163 & 0,175 & 0,179 & 0,188 \\
\hline $\begin{array}{l}\text { Centratama Telekomunikasi } \\
\text { Indonesia Tbk }\end{array}$ & CENT & 0,715 & 0,487 & 0,541 & 0,000 \\
\hline Catur Sentosa Adiprana Tbk & CSAP & 0,108 & 0,113 & 0,125 & 0,125 & 0,000 \\
\hline Electronic City Indonesia Tbk & ECII & 0,110 & 0,148 & 0,190 & 0,190 & 0,127 \\
\hline Erajaya Swasembada Tbk & ERAA & 0,053 & 0,061 & 0,056 & 0,064 & 0,068 \\
\hline Golden Retailindo Tbk & GOLD & 0,716 & 0,773 & 0,820 & 1,306 & 0,556 \\
\hline Hero Supermarket Tbk & HERO & 0,204 & 0,251 & 0,251 & 0,264 & 0,289 \\
\hline Kokoh Inti Arebama Tbk & KOIN & 0,144 & 0,165 & 0,178 & 0,191 & 0,174 \\
\hline Matahari Department Store Tbk & LPPF & 0,382 & 0,371 & 0,371 & 0,372 & 0,384 \\
\hline MitraAdiperkasaTbk & MAPI & 0,421 & 0,418 & 0,427 & 0,423 & 0,413 \\
\hline Midi Utama Indonesia Tbk & MIDI & 0,192 & 0,197 & 0,192 & 0,195 & 0,205 \\
\hline Matahari Putra Prima Tbk & MPPA & 0,126 & 0,126 & 0,141 & 0,157 & 0,203 \\
\hline Ramayana Lestari Sentosa Tbk & RALS & 0,290 & 0,299 & 0,319 & 0,315 & 0,330 \\
\hline Supra Boga Lestari Tbk & RANC & 0,240 & 0,257 & 0,253 & 0,237 & 0,244 \\
\hline Sona Topas Tourism Tbk & SONA & 0,288 & 0,343 & 0,404 & 0,441 & 0,400 \\
\hline Tiphone Mobile Indonesia Tbk & TELE & 0,018 & 0,021 & 0,021 & 0,026 & 0,027 \\
\hline
\end{tabular}

\section{Appendix 4}

Summary of Proxy 2: differentiation strategy

\begin{tabular}{|l|l|l|l|l|c|c|}
\hline \multirow{2}{*}{ Names of Company } & \multirow{2}{*}{ Stock Code } & \multicolumn{4}{c|}{ R\&D/SALES } \\
\cline { 3 - 7 } & & 2014 & 2015 & 2016 & 2017 & 2018 \\
\hline Ace Hardware Indonesia Tbk & ACES & 0,000 & 0,001 & 0,001 & 0,000 & 0,000 \\
\hline Sumber Alfaria Trijaya Tbk & AMRT & 0,000 & 0,000 & 0,000 & 0,000 & 0,000 \\
\hline $\begin{array}{l}\text { Centratama Telekomunikasi } \\
\text { Indonesia Tbk }\end{array}$ & CENT & 0,083 & 0,078 & 0,031 & 0,000 \\
\hline Catur Sentosa Adiprana Tbk & CSAP & 0,001 & 0,001 & 0,001 & 0,001 & 0,000 \\
\hline Electronic City Indonesia Tbk & ECII & 0,001 & 0,002 & 0,000 & 0,000 & 0,001 \\
\hline Erajaya Swasembada Tbk & ERAA & 0,000 & 0,000 & 0,000 & 0,001 & 0,000 \\
\hline Golden Retailindo Tbk & GOLD & 0,004 & 0,005 & 0,013 & 0,566 & 0,028 \\
\hline Hero Supermarket Tbk & HERO & 0,002 & 0,001 & 0,002 & 0,002 & 0,003 \\
\hline Kokoh Inti Arebama Tbk & KOIN & 0,003 & 0,001 & 0,001 & 0,000 & 0,001 \\
\hline Matahari Department Store Tbk & LPPF & 0,001 & 0,002 & 0,002 & 0,001 & 0,002 \\
\hline MitraAdiperkasaTbk & MAPI & 0,001 & 0,001 & 0,003 & 0,003 & 0,003 \\
\hline Midi Utama Indonesia Tbk & MIDI & 0,003 & 0,003 & 0,002 & 0,002 & 0,002 \\
\hline Matahari Putra Prima Tbk & MPPA & 0,000 & 0,000 & 0,003 & 0,004 & 0,004 \\
\hline Ramayana Lestari Sentosa Tbk & RALS & - & 0,000 & 0,001 & 0,001 & 0,001 \\
\hline Supra Boga Lestari Tbk & RANC & 0,007 & 0,014 & 0,003 & 0,001 & 0,001 \\
\hline Sona Topas Tourism Tbk & SONA & - & 0,000 & 0,007 & 0,003 & 0,001 \\
\hline Tiphone Mobile Indonesia Tbk & TELE & 0,000 & 0,000 & 0,000 & 0,000 & 0,000 \\
\hline
\end{tabular}




\section{Appendix 5}

Summary of Proxy 3: differentiation strategy

\begin{tabular}{|l|l|l|l|l|c|c|}
\hline \multirow{2}{*}{ Names of Company } & \multirow{2}{*}{ Stock Code } & \multicolumn{4}{c|}{ SALES/COGS } \\
\cline { 3 - 7 } & & 2014 & 2015 & 2016 & 2017 & 2018 \\
\hline Ace Hardware Indonesia Tbk & ACES & 1,986 & 1,934 & 1,906 & 1,910 & 1,913 \\
\hline Sumber Alfaria Trijaya Tbk & AMRT & 1,221 & 1,229 & 1,236 & 1,240 & 1,243 \\
\hline $\begin{array}{l}\text { Centratama Telekomunikasi } \\
\text { Indonesia Tbk }\end{array}$ & CENT & 1,546 & 1,214 & 1,232 & 1,242 \\
\hline Catur Sentosa Adiprana Tbk & CSAP & 1,152 & 1,154 & 1,160 & 1,165 & 1,279 \\
\hline Electronic City Indonesia Tbk & ECII & 1,252 & 1,238 & 1,230 & 1,176 & 1,174 \\
\hline Erajaya Swasembada Tbk & ERAA & 1,101 & 1,098 & 1,081 & 1,096 & 1,098 \\
\hline Golden Retailindo Tbk & GOLD & 6,717 & 4,971 & 3,103 & 2,901 & 2,899 \\
\hline Hero Supermarket Tbk & HERO & 1,314 & 1,311 & 1,302 & 1,353 & 1,359 \\
\hline Kokoh Inti Arebama Tbk & KOIN & 1,224 & 1,239 & 1,238 & 1,235 & 1,203 \\
\hline Matahari Department Store Tbk & LPPF & 2,825 & 2,754 & 2,700 & 2,686 & 2,665 \\
\hline MitraAdiperkasaTbk & MAPI & 1,992 & 1,861 & 1,879 & 1,945 & 1,930 \\
\hline Midi Utama Indonesia Tbk & MIDI & 1,277 & 1,315 & 1,332 & 1,345 & 1,330 \\
\hline Matahari Putra Prima Tbk & MPPA & 1,188 & 1,210 & 1,197 & 1,204 & 1,087 \\
\hline Ramayana Lestari Sentosa Tbk & RALS & 1,554 & 1,537 & 1,564 & 1,603 & 1,649 \\
\hline Supra Boga Lestari Tbk & RANC & 1,354 & 1,352 & 1,322 & 1,326 & 1,328 \\
\hline Sona Topas Tourism Tbk & SONA & 1,836 & 1,874 & 1,895 & 1,804 & 1,860 \\
\hline Tiphone Mobile Indonesia Tbk & TELE & 1,064 & 1,059 & 1,058 & 1,061 & 1,059 \\
\hline
\end{tabular}

\section{Appendix 6}

Summary of productivity

\begin{tabular}{|l|l|l|l|l|c|c|}
\hline \multirow{2}{*}{ Names of Company } & \multirow{2}{*}{ Stock Code } & \multicolumn{4}{c|}{ PRODUCTIVITY } \\
\cline { 3 - 6 } & & 2014 & 2015 & 2016 & 2017 & 2018 \\
\hline Ace Hardware Indonesia Tbk & ACES & 1,315 & 1,313 & 1,303 & 1,310 & 1,313 \\
\hline Sumber Alfaria Trijaya Tbk & AMRT & 1,041 & 1,041 & 1,034 & 1,033 & 1,025 \\
\hline $\begin{array}{l}\text { Centratama Telekomunikasi } \\
\text { Indonesia Tbk }\end{array}$ & CENT & 1,458 & 1,135 & 1,184 & 1,242 \\
\hline Catur Sentosa Adiprana Tbk & CSAP & 1,059 & 1,054 & 1,050 & 1,053 & 1,279 \\
\hline Electronic City Indonesia Tbk & ECII & 1,183 & 1,141 & 1,101 & 1,053 & 1,070 \\
\hline Erajaya Swasembada Tbk & ERAA & 1,069 & 1,061 & 1,045 & 1,051 & 1,049 \\
\hline Golden Retailindo Tbk & GOLD & 2,509 & 2,219 & 1,775 & 2,750 & 2,606 \\
\hline Hero Supermarket Tbk & HERO & 1,182 & 1,162 & 1,154 & 1,195 & 1,183 \\
\hline Kokoh Inti Arebama Tbk & KOIN & 1,107 & 1,103 & 1,082 & 1,074 & 1,064 \\
\hline Matahari Department Store Tbk & LPPF & 1,880 & 1,867 & 1,841 & 1,803 & 1,733 \\
\hline MitraAdiperkasaTbk & MAPI & 1,158 & 1,120 & 1,112 & 1,142 & 1,149 \\
\hline Midi Utama Indonesia Tbk & MIDI & 1,042 & 1,063 & 1,060 & 1,064 & 1,044 \\
\hline Matahari Putra Prima Tbk & MPPA & 1,138 & 1,175 & 1,154 & 1,153 & 1,013 \\
\hline Ramayana Lestari Sentosa Tbk & RALS & 1,351 & 1,329 & 1,347 & 1,378 & 1,415 \\
\hline Supra Boga Lestari Tbk & RANC & 1,111 & 1,109 & 1,080 & 1,095 & 1,090 \\
\hline Sona Topas Tourism Tbk & SONA & 1,423 & 1,368 & 1,304 & 1,223 & 1,275 \\
\hline Tiphone Mobile Indonesia Tbk & TELE & 1,059 & 1,055 & 1,053 & 1,054 & 1,051 \\
\hline
\end{tabular}




\section{Appendix 7}

Summary of bankruptcy risk

\begin{tabular}{|l|l|c|c|c|c|c|}
\hline \multirow{2}{*}{ Names of Company } & \multirow{2}{*}{ Stock Code } & \multicolumn{4}{c|}{ BANKRUPTCY RISK } \\
\cline { 4 - 7 } & & 2013 & 2014 & 2015 & 2016 & 2017 \\
\hline Ace Hardware Indonesia Tbk & ACES & 13,947 & 16,656 & 17,177 & 16,426 & 19,023 \\
\hline Sumber Alfaria Trijaya Tbk & AMRT & 6,500 & 4,408 & 5,051 & 4,283 & 4,158 \\
\hline $\begin{array}{l}\text { Centratama Telekomunikasi } \\
\text { Indonesia Tbk }\end{array}$ & CENT & 10,469 & 3,569 & 3,787 & 2,883 & 1,430 \\
\hline Catur Sentosa Adiprana Tbk & CSAP & 2,523 & 3,015 & 2,643 & 2,761 & 2,586 \\
\hline Electronic City Indonesia Tbk & ECII & 8,964 & 6,117 & 6,944 & 4,968 & 6,730 \\
\hline Erajaya Swasembada Tbk & ERAA & 4,280 & 3,719 & 3,337 & 3,712 & 4,460 \\
\hline Golden Retailindo Tbk & GOLD & 5,295 & 5,404 & 4,637 & 1,429 & 1,108 \\
\hline Hero Supermarket Tbk & HERO & 4,989 & 4,393 & 3,333 & 4,007 & 3,187 \\
\hline Kokoh Inti Arebama Tbk & KOIN & 4,546 & 3,276 & 2,711 & 2,518 & 2,501 \\
\hline Matahari Department Store Tbk & LPPF & 10,539 & 13,495 & 16,841 & 14,101 & 9,860 \\
\hline MitraAdiperkasaTbk & MAPI & 2,811 & 2,673 & 2,527 & 2,677 & 3,317 \\
\hline Midi Utama Indonesia Tbk & MIDI & 3,143 & 3,192 & 3,098 & 2,443 & 2,628 \\
\hline Matahari Putra Prima Tbk & MPPA & 4,679 & 6,602 & 4,626 & 3,631 & 1,285 \\
\hline Ramayana Lestari Sentosa Tbk & RALS & 6,708 & 5,560 & 5,013 & 6,843 & 7,409 \\
\hline Supra Boga Lestari Tbk & RANC & 4,470 & 3,629 & 3,866 & 5,324 & 4,543 \\
\hline Sona Topas Tourism Tbk & SONA & 5,229 & 4,623 & 4,588 & 3,502 & 3,726 \\
\hline Tiphone Mobile Indonesia Tbk & TELE & 4,913 & 5,452 & 5,269 & 5,602 & 5,338 \\
\hline
\end{tabular}

